\author{
Stanisław Lisiecki* \\ Jacek Kubera*
}

\title{
O ZASADNOŚCI BADAŃ NAD TOŻSAMOŚCIĄ DZIELNIC MIAST. POSZUKIWANIE NOWYCH-STARYCH TOŻSAMOŚCI
}

\begin{abstract}
Abstrakt. W artykule dzielnica traktowana jest jako przestrzeń społeczna, która dziś funkcjonuje w obrębie dużego miasta, niegdyś zaś znajdowała się poza nim jako w pewnym stopniu odrębna i autonomiczna całość: wioska, obszar podmiejski, osobne osiedle czy małe miasto leżące przy większym ośrodku. W nawiązaniu do genezy miast, w tekście omówione są wybrane elementy tożsamości dzielnic miejskich. Następnie przedstawia się różne, charakterystyczne dla wybranych szkół w socjologii miasta, sposoby rozumienia i opisywania dzielnicy. Pośród wielu możliwych perspektyw Autorzy za szczególnie przydatną uważają tę, którą nazwać można ujęciem tożsamościowym. Tradycję badań w tym nurcie rozpoczął w Poznaniu Florian Znaniecki, a ich specyficzną cechą jest zwrócenie uwagi na autostereotyp mieszkańców danej przestrzeni oraz na badanie tego autostereotypu w kontekście innych tożsamości (np. narodowych, klasowych, religijnych). Na przykładzie poznańskich dzielnic, takich jak Śródka, Jeżyce, Święty Marcin czy Wilda, w tekście mówi się o zjawiskach kształtujących współcześnie tożsamości dzielnic w mieście.
\end{abstract}

Słowa kluczowe: miasto, dzielnica, tożsamość dzielnicy, identyfikacja z dzielnica, Poznań.

\section{1. „Od wsi do miasta i... z powrotem"}

W dzisiejszej socjologii egzystują obok siebie dwa sprzeczne poglądy. Z jednej strony, współczesne metropolis traktuje się jako miasto pozbawione podłoża kulturowego i jako jedynie przestrzeń przepływów, której mieszkańcy są w ciagłym ruchu (J a ło w i e ck i 2014: 22-23). Z drugiej strony, istnieje i nadal funkcjonuje, opisany swego czasu przez Maxa Webera w Die Stadt (wyd. 1921), średniowieczny wzorzec zakładający łatwe identyfikowanie miasta przez jego mieszkańców. Do koncepcji tej nawiązują m.in. zapisy Karty Lipskiej, w której zwarte w zabudowie, oparte na więziach obywatelskich i na obywatelskim poczu-

* Uniwersytet im. Adama Mickiewicza, Instytut Socjologii, Pracownia Socjologii Miasta, lisiecki@amu.edu.pl

** Instytut Zachodni w Poznaniu, kubera@iz.poznan.pl 
ciu wspólnoty „Miasto Europejskie” widnieje jako jeden z filarów zrównoważonego rozwoju miast (B illert 2012: 37-40).

W tym kontekście warto przypomnieć, że miasta takie jak Paryż, Berlin, a w Polsce Poznań, Kraków czy Wrocław powstały dzięki połączeniu dawnego średniowiecznego ośrodka z przyległymi obszarami wiejskimi, półwiejskimi lub miejskim, ale o mniejszym znaczeniu niż ten ośrodek, inne miasta zaś, tak jak Zabrze, to wynik scalenia osobno powstałych osiedli miejskich lub przemysłowych (por. Ry bicki 1972: 163). Być może dlatego Christian To palov (2002) woli mówić nie o tym, że miasta są podzielone na części (co sugerowałoby, że mamy do czynienia $\mathrm{z}$ jednolitą całością, której każdy możliwy podział będzie równie arbitralny i uzasadniony), ale że istnieją stykające się ze sobą, zestawione obok siebie miasta, których archipelagom lub, jak kto woli, aglomeracjom, nadaje się takie nazwy jak Paryż, Jokohama czy Londyn.

W Paryżu nazwy Montparnasse, Montmartre, Belleville, Cité, Marais czy Faubourg Saint-Germain nie tylko zaświadczają o „długim trwaniu” tych dawnych wiejskich, podmiejskich i miejskich obszarów, ale także są elementem codziennych doświadczeń paryżan zamieszkujących Rive Gauche albo Rive Droit, mieszczański zachód albo robotniczy wschód, i źródłem wielu ważnych ich społecznych identyfikacji. Z kolei dzisiejszy Berlin złożony jest z dwóch części, dawnej stolicy NRD (Berlina Wschodniego) i Berlina Zachodniego, w których patrząc z perspektywy amerykańskiej szkoły ekologicznej - istnieją lepsze (Zehlendorf) i gorsze dzielnice (Neukölln). W tym wielokulturowym i wieloetnicznym mieście, gdzie żyje 470 tys. obcokrajowców (w tym 47 tys. Polaków), znajduje się dzielnica turecka (Kreuzberg) i dzielnica romska (Marzahn), podobnie jak polskie były i są Jackowo w Chicago czy Greenpoint w Nowym Jorku. Jak twierdzi Dorota D a n i e l e w i c z (2014: 48), „Berlińczycy pytając się nawzajem o miejsce zamieszkania, pragną wiedzieć z jakiej się jest wioski, czyli Kietzu. Nie dałoby się wytrzymać życia w metropolii, bez identyfikacji z niewielkimi centrami (Friedenau, Gruenewald, Kladow, Niederschönhausen). Te berlińskie «Kietze» często rzeczywiście były wioskami i zostały w pewnym momencie włączone do rozrastającego się miasta".

Również w Polsce odradzają się tożsamości dzielnic miast. Szczególnie widoczne jest to w Krakowie i w Poznaniu, gdzie dzielnice odpowiadają kolejnym wchłanianym przez miasto wioskom, miasteczkom i osiedlom, a jednocześnie ogólnomiejska przestrzeń symboliczna silnie wpisana jest w polski dyskurs narodowy (K u b i c k i 2010: 63-64). Nawet jeśli w innych miastach, takich jak Wrocław, poczucie związku z dzielnicą ustępuje identyfikacji z własnym domem lub mieszkaniem i z całym miastem (P l u ta 2006b: 66-74), wszędzie, w aspektach, które chcielibyśmy w dalszej kolejności omówić, pojęcie „dzielnica” odnosi się do przestrzeni społecznej o własnej specyficznej tożsamości.

W tym kontekście warto przywołać słowa Benjamina Barbera, który stwierdza, że mimo wydawałoby się dominującej mody na definiowanie się przez miasto 
„marzenia o wsi snute w ciemnym sercu miasta trzymają się mocno” (B a rb er 2014: 47). Gdy autor książki Gdyby burmistrzowie rządzili światem pisze o konieczności uwzględnienia w dyskusji o mieszkańcach wielkich miast ich potrzeby „określania swojej tożsamości przez zamieszkałą przestrzeń” ( t a m że), na myśl od razu przychodzą dzielnice - po pierwsze, przyswojony przez mieszkańców obszar miasta, w którym realizują oni swe codzienne praktyki, po drugie, mniej lub bardziej spójna jednostka społeczna, której znaczna część członków zna się nawzajem choćby z widzenia (J a ł o w i e c ki 1980: 10-12; por. definicja dzielnicy podstawowej: P i otrow s ki 1966: 24).

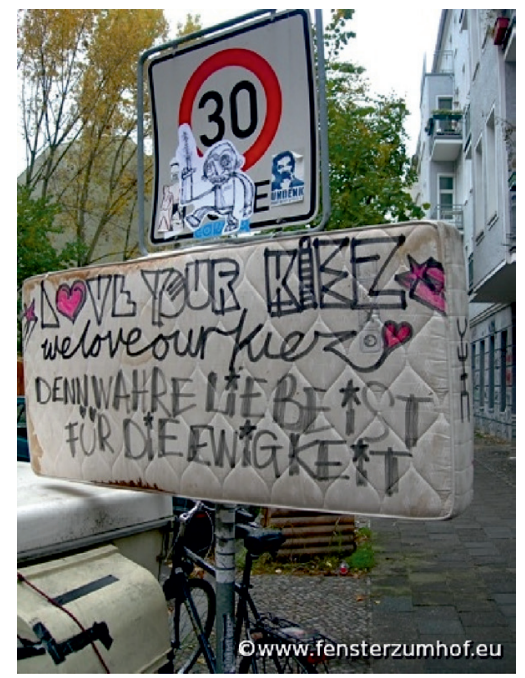

Ryc. 1. „Love your Kiez, we love our Kiez, ponieważ prawdziwa miłość trwa wiecznie” Źródło: http://www.fensterzumhof.eu/bilder/v/Berliner-Seitenblicke/berlin-liebe-love-kiez.html (dostęp 29.06.2015)

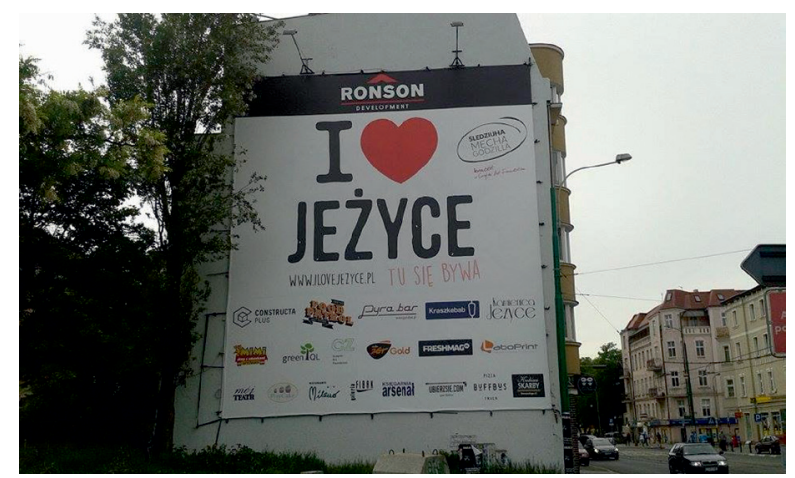

Ryc. 2. Jeżyce w Poznaniu - dzielnica, do której warto się przyznawać

Źródło: Fot. J. Kubera (2015) 


\section{Dzielnice ujęte w ramy socjologii miasta}

Stawiane przez mieszkańców miast pytanie „Z jakiej dzielnicy, wioski jesteś?", można próbować odnieść do przynajmniej trzech kontekstów teoretycznych. Po pierwsze, skupiając się na tym, czym w ogóle jest przestrzeń społeczna (por. M a j e r 2010: 43-44), można odwołać się do klasyków socjologii: É. Durkheima (1999), dla którego przestrzeń zmienia się wraz ze społeczeństwem; G. S immla (2008), który uważał, że przestrzeń jest dziełem psychiki; czy wreszcie do F. Zn a ni e c ki e g o (1938), twórcy pojęcia „wartość przestrzenna”, autora koncepcji traktowania przestrzeni ze współczynnikiem humanistycznym. Parafrazując Z n a n i e c k i e go (1938: 91), powiemy, że każda dzielnica jest wartością przestrzenną - jedną z wielu doświadczanych przez ludzi: ograniczoną, niepodzielną, zmienna, jakościowo różną od innych, dodatnio lub ujemnie ocenianą. Nie ma charakteru obiektywnego, powszechnego, bezjakościowego, nie jest nieograniczona ani nieograniczenie podzielna. Jest w różny sposób wartościowana przez odmienne ludzkie zbiorowości (klasowe, społeczno-zawodowe, etniczne, religijne, o określonym stylu życia), a przez niektóre z nich - traktowana jako ich własność (tak rozumianym właścicielem mogą być mieszkańcy lub użytkownicy dzielnicy, ale niekiedy wymaga się od nich, aby jednocześnie reprezentowali jeszcze inne kategorie społeczne żyjące w mieście).

Po drugie, zastanawiając się nad tym, czym jest miasto i dlaczego składa się na nie wiele przestrzeni społecznych, można sięgnać do badaczy z kręgu szkoły chicagowskiej: R. E. Parka, W. Burgessa i R. Redfilda, którzy badając procesy aglomeracyjne zachodzące na początku XX wieku w miastach amerykańskich, opisywali procesy centralizacji, segregacji, koncentracji, segmentacji, inwazji, sukcesji i rywalizacji. Co prawda, cechą charakterystyczną miast jest ich heterogeniczność, jednak w każdym z nich znajdziemy dzielnice, których skład ludności pod względem występowania jakiejś ważnej społecznej cechy, takiej jak przynależność narodowo-etniczna czy warstwowo-klasowa, jest w danym momencie bardziej lub mniej jednorodny (Rybi cki 1972: 184). Jak pisał Janusz Ziółkowski, autor wielu prac z zakresu ekologii społecznej w Polsce: „Jednostka dążąc do znalezienia sobie w obrębie przestrzeni miejskiej jak najlepszego miejsca, odpowiadającego jej indywidualnym i społecznym potrzebom, ma tendencję do zamieszkiwania wespół z członkami grupy miejskiej, jednorodnymi z nią pod określonym względem. Fakt zamieszkiwania danej ulicy czy dzielnicy miasta przez takie czy inne jednostki, przynależące do określonych grup społecznych, jest w pierwszym rzędzie zdeterminowany ekonomicznie. Ale działają tu również wtórne czynniki pozaekonomiczne. Jednym $\mathrm{z}$ nich jest tradycja czy konserwatyzm, nakazujące zamieszkiwać dane partie miasta, mimo że znikły już korzyści ekonomiczne i społeczne, które kiedyś ten wybór usprawiedliwiały" (Zi ół kow ski 1960: 190; zob. Zi ółk ow ski 1965). Utrzymywanie się, niezależnie od postępującej urbanizacji, industrializacji i powojennej migracji do miast, od- 
miennych „obszarów społecznych” w miastach w Polsce potwierdzały badania prowadzone m.in. w Sosnowcu (Zi ółk ow s k i 1960), w Łodzi (P i otrow s ki 1966), w Lublinie i w Toruniu (P i ó r o 1962) czy we Wrocławiu (J ało w i e c k i 1968). Dla Poznania ważny punkt odniesienia stanowią tutaj badania osiedli Winogrady i Rataje, których rezultatem były prace Janiny S tank i e w i c z i Jerzego Walk o w i a k a (np. Optymalizacja działalności społeczno-wychowawczej. Socjologiczne studium o osiedlach mieszkaniowych, 1979) oraz prace pod redakcją Stanisława Wawryniuka (np. Placówki kulturalne na osiedlach mieszkaniowych. Z badań nad życiem społeczno-kulturalnym Osiedla Piastowskiego, 1978).

Po trzecie, wreszcie, na problem identyfikacji z konkretną przestrzenią miasta można spojrzeć z punktu widzenia tożsamości tej przestrzeni i ta perspektywa wydaje nam się najbardziej interesująca. Dzielnicę traktujemy tutaj jako „miasto w mieście", stąd wcześniej w socjologii stawiane konstatacje na temat tożsamości miasta proponujemy odnosić do tożsamości dzielnic. O tożsamości tej zatem możemy mówić tylko wówczas, gdy jest ona obiektem ludzkich postaw (P i o t r o w ski 1994: 171). Określają ją najbardziej istotne cechy miasta (t a m że), obejmujące zarówno subsystem społeczny, jak i subsystem urbanistyczny (Wallis 1990: 79). Przy czym tożsamość dzielnicy to nie tyle suma tożsamości owych dwóch subsystemów, co wynik ich wzajemnego oddziaływania, relacji między ludźmi (podmiot) a przestrzenią (przedmiot, który w relacji zyskuje cechy podmiotu) (por. M a d u row i c z 2007: 48-49).

Badanie tożsamości dzielnicy, podobnie jak badanie miasta, polegać może na postawieniu pytań o autostereotyp. W nawiązaniu do tradycji badań ,miasta w świadomości”, rozpoczętej w Poznaniu przez F. Znanieckiego, kontynuowanej później w tym mieście i w innych ośrodkach w Polsce, kwestia autostereotypu pojawia się w odniesieniu do obydwu wyróżnionych przez A. Wallisa subsystemów. Pytamy więc zarówno o cechy miasta (cechy przestrzeni miejskiej), jak i o „typowe” cechy jego mieszkańców (por. P lut a 2006a: 233 i nast.). Te same zagadnienia odnieść można do samych dzielnic, sięgając choćby do odezw konkursowych na wypowiedzi o mieście, które zadawali socjologowie w Poznaniu - w 1928 r. (Znaniecki 1931), w 1964 r. (Znan i e cki i Zi ółk ow ski 1984) i w 1994 r. (Cichocki i Podemski 1999). Po przeformułowaniu treści tych odezw, uzyskujemy wiele pytań, które warto zadać respondentom w (wykorzystujących różne metody pozyskiwania danych) badaniach tożsamości dzielnicy miasta. Poniżej wymieniamy niektóre z tak przekształconych pytań - tam, gdzie to niezbędne, wykorzystując przykład poznańskich Jeżyc:

- Co Twoim zdaniem jest najbardziej ,jeżyckie” (co uważasz za symbol dzielnicy)?

- Jaką dzielnicą są według Ciebie Jeżyce?

- Jaką funkcję pełnią dla miasta Jeżyce?

- Jak oceniasz tę dzielnicę na tle innych, znanych Ci dzielnic w mieście? Czym różnią się Jeżyce od tych dzielnic, w czym podobają Ci się więcej, a w czym mniej? 
- Jacy są mieszkańcy dzielnicy?

- Co sądzisz o mieszkańcach dzielnicy w ogóle? Co sądzisz o „starych” i o „nowych” mieszkańcach? Co sądzisz o poszczególnych kategoriach społecznych zamieszkujących dzielnicę?

- Czy Twoim zdaniem istnieją cechy wspólne wszystkich mieszkańców dzielnicy?

- Czy czujesz się Jeżyczaninem / Jeżyczanką? Co Cię najbardziej wiąże z tą dzielnicą?

- Co Ci się najbardziej podoba w dzielnicy? Co skłania Cię do pobytu w niej?

- Jakie korzyści zawdzięczasz dzielnicy?

- Czy w dzielnicy możesz zaspokajać wszystkie swoje potrzeby materialne i kulturalne?

- Czy chciałbyś / chciałabyś wyprowadzić się z Jeżyc? Jeśli tak, to dokąd i dlaczego?

- Co Ci się najbardziej nie podoba w dzielnicy? Co zniechęca Cię do pobytu w niej?

- Co robiłeś / robiłaś w swoim życiu na korzyść dzielnicy?

- Jakie szkody mimowolnie lub świadomie wyrządziłeś / wyrządziłaś dzielnicy?

- Jakich krzywd doznałaś / doznałeś od dzielnicy?

- Jakie jest Twoje zdanie o radzie osiedla Jeżyce?

- Co sądzisz o wydarzeniach kulturalnych i innych odbywających się w dzielnicy?

- Jak zmieniała się dzielnica w ostatnich 25 latach? Które ze zmian uważasz za najważniejsze? Kto Twoim zdaniem zyskał, a kto stracił na zmianach w dzielnicy?

- W jakim kierunku powinna się przede wszystkim rozwijać dzielnica?

- Jakie musiałyby stać się Jeżyce, aby stać się ideałem dzielnicy?

$\mathrm{Z}$ reguły, z punktu widzenia jednostki, dzielnica zamieszkania jest jedną z najbardziej doświadczanych i przetwarzanych przez nią części miasta (por. Certe au 2011: 128-131), co sprzyja identyfikowaniu się z nią w większym stopniu niż z innym dzielnicami. Stwierdzeniu na temat własnej przynależności do zbiorowości mieszkańców danej dzielnicy towarzyszyć może, lecz nie musi, poczucie, że tworzy się z nimi wspólnotę czy solidarną grupę o bardziej lub mniej wyraźnych granicach i wynikających $\mathrm{z}$ tego faktu określonych prawach i obowiązkach grupowych. Ujawniana $w$ różnych sytuacjach identyfikacja z dzielnica, podobnie jak inne identyfikacje, nie dokonuje się w oderwaniu od kontekstu, ale zakłada istnienie odpowiedniego uzasadnienia. Uzyskanie pozytywnej odpowiedzi na pytanie „Czy czujesz się Jeżyczaninem / Jeżyczanką?” pozwala nam zadać kolejne - o argumenty identyfikacji z dzielnica, których zebranie pozwoli np. na zbadanie występujących w zbiorowej świadomości relacji między przynależnością do kategorii mieszkańców dzielnicy a przynależnością do innych, szerszych zbiorowości społecznych: narodowych, etnicznych, społeczno-zawodowych, kla- 
sowych itd. Owe inne identyfikacje mogą być uważane za argument sprzyjający bądź niesprzyjający poczuciu, że jest się np. „prawdziwym” Jeżyczaninem. Wydaje się, że im dłuższa lista dodatkowych, innych niż fakt zamieszkiwania, argumentów koniecznych dla poczucia, że w danej dzielnicy jest się u siebie, tym większe szanse, że dzielnica będzie kiedyś lub już jest przykładem enklawy społecznej (por. M a chaj, Gołdy ka 2007).

$\mathrm{W}$ omawianej tu perspektywie dzielnica rozpatrywana jest zatem w relacji z innymi wyróżnianymi przez socjologów aspektami rzeczywistości społecznej, które mogą w różnym stopniu być istotne dla zbiorowych i jednostkowych tożsamości (ryc. 3). Takim kontekstem, który nie pojawiał się we wspominanych wyżej trzech odezwach konkursowych, a który dostrzeżono w kolejnych, nawiązujących do nich, poznańskich badaniach (K a c z mare k 2002), są także rozmaite przestrzenie społeczne w mieście (a nie miasto traktowane jako całość), zdolne do wytwarzania własnych, odrębnych tożsamości. Socjolog miasta badający dzielnice w ujęciu tożsamościowym z pewnością więc będzie się interesował również relacjami, w jakie ujęte są przestrzeń społeczna miasta i poszczególnych jego dzielnic (np. „Co sprawia, że Wilda jest dzielnicą poznańską?”, „Którą z dzielnic uważasz za najbardziej poznańską?”) oraz dzielnice między sobą nawzajem (np. „Co odróżnia mieszkańców Wildy od mieszkańców Jeżyc?”).

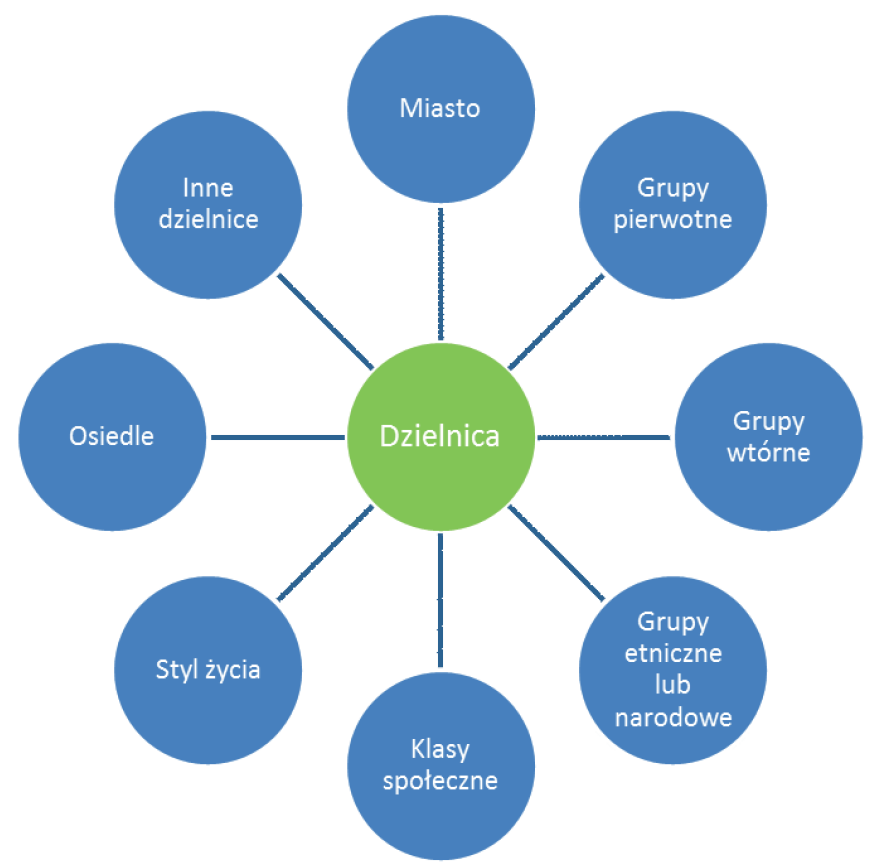

Ryc. 3. Tożsamość dzielnicy na tle innych wybranych tożsamości

Źródło: opracowanie własne. 


\section{Poznań - przejawy kształtowania się tożsamości dzielnic w mieście}

Odwołując się do przykładów poznańskich, można wskazać na obserwowane w ostatnich latach zjawiska, które szczególnie przyczyniają się do kształtowania się tożsamości dzielnic i o występowaniu tej tożsamości zaświadczają. Pierwszą dzielnica, o której warto powiedzieć, jest Śródka - dawne podgrodzie, przylegające do katedralnego Ostrowa Tumskiego, włączone w granice Poznania w 1800 r. Choć realizowane na tym stosunkowo małym obszarze działania rewitalizacyjne nie przyniosły oczekiwanej zmiany (K a ź m i e r c z a k, N ow a k, P a li ck ki, P a z d e r 2011: 157), wywołały w mieście dyskusję o Śródce ${ }^{1}$. W kontekście tych działań mieszkańcy Śródki, pewnie częściej niż zwykle, zastanawiali się nad tym, czym jest ich dzielnica, ich „wartość przestrzenna”, i co łączy ich jako jej mieszkańców. Rewitalizacja, która dotyczy zazwyczaj wybranych obszarów miasta o określonej nazwie i charakterystyce, wzmacnia więc - nawet jeśli tylko na chwilę i tylko w pewnych sytuacjach - myślenie mieszkańców dzielnicy o sobie jako „my”, odsuwając na dalszy plan znaczenia ich przynależności do pozostałych, innego rodzaju grup.

Kolejny przykład związany jest z obszarem miasta określanym jako Święty Marcin, obejmującym ulicę o tej nazwie i pobliskie, przylegające do niej budynki. Święty Marcin to dawna podmiejska osada, która wraz z podjętą na przełomie XIX i XX wieku rozbudową Poznania stała się jego reprezentatywną ulica, a w połowie XX wieku - jedną z głównych arterii łączących centralne i zachodnie obszary miasta. Podobnie jak na Śródce, kryzys ulicy i podejmowane działania naprawcze wzmogły zainteresowanie jej tożsamością. Tym, na co chcielibyśmy tutaj zwrócić uwagę, jest nazwa obszaru („Święty Marcin”, „Śródka”), która przetrwała, pomimo że zmieniał się jego status administracyjny, a także że raz zwany był on podmiejską wioską, innym razem zaś - ulicą (Święty Marcin), raz miastem, a później osiedlem (Śródka). Dzielnice, które nas tu interesują, rozumiemy w sposób, w jaki Wacław P i o tro w s k i (1966: 24) pojmował „,dzielnice podstawowe" - obecne w świadomości mieszkańców obszary o tradycyjnych, obiegowych nazwach. Istnienie nazwy pozwala na wyodrębnienie ze zbioru wszystkich mieszkańców miasta właśnie tych, którzy zamieszkują taką a nie inną dzielnicę. Dzięki temu Święty Marcin, Święty Wojciech, Wilda, Łazarz, Strzeszyn, Grunwald czy Jeżyce stanowią osobne, odrębne całości, istniejące w ramach - jak to ująłby V. Topolov - jednego archipelagu o nazwie Poznań. Całości te nie są oczywiście semantycznie puste - nazwie dzielnicy oraz nazwie jej mieszkańców różni ludzie przypisują odmienne cechy, łączą z urzeczywistnionymi bądź tylko hipotetycznymi doświadczeniami, obrazami, skojarzeniami i emocjami, wreszcie - nazwy te zestawiają (indeksuja) wraz z innymi nazwami i hierarchizują je.

${ }^{1} \mathrm{Na}$ temat przebiegu rewitalizacji Śródki i innych dzielnic poznańskich w ostatnich latach zob. artykuły w publikacjach pod redakcją K. D e rejski e go, J. Ku bery, S. Li s i e c ki e go i R. M a c y r y $(2012,2014)$. 
Wyodrębnieniu i każdorazowemu uaktywnieniu się kategorii „my”, opartej o nazwę denotującą mieszkańców dzielnicy, sprzyjają sytuacje konfliktu, gdy np. zdecydować trzeba o przyszłości ważnego dla dzielnicy miejsca, o zmianie jego wyglądu, funkcji czy znaczenia o charakterze symbolicznym. W sytuacjach tych decyduje się również o kierunku, w jakim ewoluować będzie tożsamość dzielnicy. Spór może toczyć się między różnymi grupami mieszkańców, a także między reprezentantami mieszkańców a władzami dzielnicy, władzami miasta lub innymi instytucjami, np. inwestorami. Przykładem takiego zogniskowanego wokół kategorii dzielnicy konfliktu był ten o kształt przebudowy Placu Asnyka na poznańskich Jeżycach. Część mieszkańców wraz z radą osiedla chciała uczynić z Placu „salon Jeżyc”, podczas gdy inni, w dużej mierze młodzi mieszkańcy, przeciwstawiali się tej koncepcji, organizując różne happeningi i zakładając na Facebooku grupę o tytule: „Plac Asnyka dla ludzi. Ruch przeciwko salonowi dla umarłych”. Dyskusja toczyła się w lokalnych mediach, a część protestujących przeciw „salonowi" wystartowała niedługo potem, w 2015 r., po raz pierwszy i z sukcesem w wyborach do rady osiedla. Konflikt przyczynił się do uaktywnienia działalności społecznej na rzecz Jeżyc nowych grup mieszkańców i ujawnił - jak powiedziałby B. B arb er (2014: 47) - potrzebę „określania swojej tożsamości przez zamieszkałą przestrzeń".

Wskaźnikiem tożsamości są nie tylko identyfikacje (w tym występowanie określonego autostereotypu), ale także praktyki, działanie realizujące się ze względu na fakt, że można o sobie powiedzieć np. „Jestem Jeżyczaninem”. Mieszkanie na Jeżycach czy odwiedzanie modnych, co roku przybywających, miejsc uważanych za jeżyckie sprzyja wytworzeniu się atrakcyjnego obrazu dzielnicy, sprawiającego, że „tu się bywa” (zob. ryc. 2). Podobnie jak miasta, również dzielnice mają własne różnorodne symbole i obdarzone mogą być swoistym mitem, tworzonym i utrwalanym choćby przez literaturę (por. słynna „Jeżycjada” Małgorzaty Musierowicz). Dzielnica jest przestrzenia, której doświadczamy jako mieszkańcy lub jako tylko jej bywalcy (spacerowanie, oglądanie, słuchanie itd.), jest też przestrzenią, w której urzeczywistniają się relacje nas - mieszkańców i bywalców - z innymi ludźmi (spędzanie w różny sposób czasu z innymi, życie sąsiedzkie, różne poziomy zaangażowania w sprawy dzielnicy, udział w wyborach lokalnych itd.).

Dzięki zaistniałemu kilka lat temu w Polsce fenomenowi ruchów miejskich coraz bardziej doceniane są wysiłki na rzecz tworzenia i odbudowywania wspólnot lokalnych w dzielnicach. Niekiedy dawne instytucje zastępowane są nowymi. W byłym Domu Tramwajarza na Jeżycach funkcjonuje Centrum Amarant o bardzo bogatej ofercie kulturalnej i warsztatowej. Zakładane są stowarzyszenia, takie jak Wildecka Inicjatywa Lokalna WILdzianie, której już sama pisownia sugeruje, że celem tej organizacji jest zwiększanie możliwości działania na Wildzie. Portale społecznościowe, m.in. Facebook, dowodzą z kolei istnienia nieformalnych grup mieszkańców, których członkowie chcą spotykać się na śniadaniach, obiadach, piknikach i brać udział w lokalnych świętach, festynach i w coraz popularniej- 
szych „dniach dzielnicy” tylko dlatego, że są bliższymi lub dalszymi sąsiadami. Swoją stronę internetową, pt. „Nasz Grunwald”, ma również Inicjatywa Mieszkańców Poznańskiego Grunwaldu.

Przedstawione powyżej zjawiska, sprzyjające trwaniu tożsamości lokalnych w Poznaniu, czynią z dzielnic ciekawy obiekt badań, których wyniki mogą nam wiele powiedzieć nie tylko o kondycji samej dzielnicy, ale również o stanie rozwoju i tożsamości całego miasta.

\section{Zakończenie}

Tym, co w kontekście dotychczasowych obserwacji wydaje się szczególnie interesujące, jest badanie związku między wzmacnianiem tożsamości danej dzielnicy a jej rewitalizacją. Warto, naszym zdaniem, zastanowić się nad tym, jakie elementy określające specyfikę danej dzielnicy sprzyjają odnowie społeczno-ekonomicznej, a jakie ją utrudniają. Czy wspieranie każdej tożsamości lokalnej w mieście, takiej jaka ona jest w danym momencie, zawsze przyniesie oczekiwane efekty? Czy budowanie wspólnoty w oparciu tylko o kryterium zamieszkiwania przy akceptacji innych cech konstytuujących dzielnicę jest skuteczne z punktu widzenia celów, jakie stawia się przed rewitalizacją?

Perspektywa, w której tożsamość dzielnicy ujmowana jest w relacji z innego rodzaju tożsamościami, pozwala na wyodrębnienie tych relacji między „my” dzielnicy miasta a innego rodzaju „my”, które utrudniają pomoc dzielnicom znajdującym się w kryzysie. Podążając tym tokiem rozumowania, należy sądzić, że nie ma tożsamości dzielnic miast, które jako takie byłyby przeszkodą na drodze rewitalizacji (co oznaczałoby, że aby zrewitalizować dzielnicę, trzeba jej tożsamość całkowicie wymyślić i zaprojektować), ale że jedynie pewne jej elementy, powiązania z innymi tożsamościami (np. związanymi ze zjawiskami socjopatologicznymi) mogą odnowie szkodzić (wówczas rewitalizacja zmierzałaby do zmiany tylko w tym elemencie, np. do wyeliminowania ze stereotypu mieszkańca danej dzielnicy cechy bycia przestępcą lub człowiekiem niezaradnym). Wyodrębnienie takich elementów miałoby z pewnością zarówno spory walor poznawczy, jak i praktyczny. Ponadto, uczyniłoby rewitalizację procesem, dla którego w większym stopniu punktem wyjścia byłaby sama dzielnica i jej wewnętrzne problemy, w mniejszym zaś - wypróbowane w innych miejscach pomysły na uatrakcyjnienie, także pod względem turystycznym, dzielnicy, jednak nie zawsze odpowiadające potrzebom i wymaganiom samych mieszkańców.

Tymczasem, zapewnienie ciagłości ważnych cech tożsamości dzielnicy ma olbrzymie znaczenie dla budowania poczucia wspólnoty - żyjącej w mieście, jasno zdefiniowanej społeczności lokalnej zdolnej rozwiązywać najważniejsze problemy mieszkańców. Właśnie taka, zachowująca tożsamość, dzielnica jest w stanie skutecznie przyciagać turystów swą autentycznością, specyficznością i tradycją 
(por. Frysztacki 1994: 106). Jak pisze Joanna Karmowska (2007: 223), „[...] tożsamość kulturowa społeczności lokalnej, siła tej społeczności oparta o długotrwale budowane instytucje i zasady życia społecznego stanowi kluczowy czynnik atrakcyjności danego terenu dla wszelkiego rodzaju przyjezdnych. Ci z kolei dobrze asymilują się i znajdują swoje miejsce w stabilnej strukturze społecznej, identyfikując się z miejscem i w konsekwencji aktywnie działając dla jego zachowania i zrównoważonego rozwoju".

W Pracowni Socjologii Miasta działającej w Instytucie Socjologii UAM, wraz z pracownikami Zakładu Historii Gospodarczej związanego z Instytutem Historii UAM już od kilku lat zastanawiamy się nad miastami w Polsce i warunkami ich odnowy. Ponieważ w zredagowanych przez nas dotychczas publikacjach wielokrotnie pojawiał się wątek wpływu rewitalizacji na tożsamość dzielnic, postanowiliśmy w niniejszym artykule - na tyle, na ile pozwalają jego objętościowe ramy - zwrócić uwagę na odwrotny związek, w którym przebieg dobrej rewitalizacji warunkowany byłby uwzględnieniem specyfiki danej dzielnicy w mieście. Zauważane dziś coraz częściej przejawy myślenia w kategoriach przynależności dzielnicowej można uznać za pierwszy, niezbędny etap rewitalizacji dzielnicy.

Na koniec powiedzmy, że jeśli w niniejszym artykule szczególnie kładliśmy nacisk na Poznań i jego przestrzenie społeczne o różnych nazwach, to wynikało to z kilku powodów: genezy rozwoju Poznania, który wchłaniał kolejne wioski i podmiejskie osiedla, tradycji badań nad przestrzenią miejską w świadomości mieszkańców oraz z dostrzeżenia zwiększającej się liczby sytuacji, w których identyfikacja $\mathrm{z}$ dzielnica, czyli $\mathrm{w}$ wielu przypadkach $\mathrm{z}$ dawną wsią, jest identyfikacją podstawową, regulującą wzajemne oddziaływanie mieszkańców i użytkowników miasta.

\section{Bibliografia}

B arber B. R. (2014), Gdyby burmistrzowie rzqdzili światem. Dysfunkcyjne kraje, rozkwitajqce miasta, tłum. H. Jankowska i K. Makaruk, Warszawskie Wydawnictwo Literackie Muza SA, Warszawa.

Billert A. (2012), Założenia, modele i planowanie polityki rozwoju miasta. Próba konfrontacji dwóch światów jednej Unii Europejskiej, [w:] D e r e j s k i K., K u b e r a J., L i s i e c k i S., M a c y r a R. (red.), Deklinacja odnowy miast. $Z$ dyskusji nad rewitalizacja w Polsce, Wydawnictwo Naukowe Wydziału Nauk Społecznych UAM, Poznań, s. 21-53.

Certe a u M. de (2011), Duchy miasta, [w:] Certe a u M. de, G iard L., Mayol P. (red.), Wynaleźć codzienność. 2: Mieszkać, gotować, Wydawnictwo Uniwersytetu Jagiellońskiego, Kraków.

Ci c h o c k i R., P o d e m s ki K. (1999), Miasto w świadomości swoich mieszkańców, Wydawnictwo Fundacji Humaniora, Poznań.

Danielewicz D. (2014), Berlin. Twór bez muru, „Polityka”, wydanie specjalne „Miasta i ludzie", $\mathrm{nr} 10$.

De re j s ki K., K u be r a J., L i s i e c k i S., M a c y r a R. (2012), Deklinacja odnowy miast. Z dyskusji nad rewitalizacja w Polsce, Wydawnictwo Naukowe Wydziału Nauk Spoołecznych UAM, Poznań. 
Derej ski K., Kubera J., Li s i e cki S., Mac yra R. (2014), Nowe życie w mieście? Dylematy rewitalizacji, Wydawnictwo Naukowe Wydziału Nauk Społecznych UAM, Poznań.

Durkheim É. (1999), O podziale pracy społecznej, thum. K. Wakar, Wydawnictwo Naukowe PWN, Warszawa.

Frysztacki K. (1994), Dynamika społeczności lokalnych wobec problemów społecznych, [w:] M a c h a j I., S ty k J. (red.), Stare i nowe struktury społeczne w Polsce. T. 1: Miasto, Wydawnictwo Uniwersytetu im. Marii Curie-Skłodowskiej, Lublin, s. 105-111.

Gołd y k a L., M a c haj I. (red.) (2007), Enklawy życia społecznego, Wydawnictwo Naukowe Uniwersytetu Szczecińskiego, Szczecin.

J a ło w i e c k i B. (1968), Osiedle i miasto. Studium socjologiczno-urbanistyczne jednostek mieszkaniowych Wroctawia, Arkady, Warszawa.

J ałow i e cki B. (1980), Człowiek w przestrzeni miasta, Śląski Instytut Naukowy, Katowice.

J a ło w i e c ki B. (2014), Metropolie rzadzq światem, „Polityka”, wydanie specjalne „Miasta i ludzie", nr 10.

K a c z m a r e k J. (2002), Poznań w fotografii i świadomości mieszkańców, „Przegląd Zachodni”, nr 3.

Karmow ska J. (2007), Promocja wewnętrzna w historycznym mieście europejskim jako czynnik ksztattujacy jakość życia społeczności lokalnej, [w:] M aj e r A. (red.), Socjologia miasta. Nowe dziedziny badań, Wydawnictwo Uniwersytetu Łódzkiego, Łódź, s. 213-236.

Kaźmi e r c zak B., N ow ak M., P a li cki S., P a zder D. (2011), Oceny rewitalizacji. Studium zmian na poznańskiej Śródce, Wydawnictwo Naukowe Wydziału Nauk Społecznych UAM, Poznań.

K u b i c k i P. (2010), Nowi Mieszczanie - w poszukiwaniu nowych tożsamości miejskich, [w:] M a d u row i z M. (red.), Wartościowanie wspótczesnej przestrzeni miejskiej, Wydział Geografii i Studiów Regionalnych Uniwersytetu Warszawskiego, Urząd Miasta Stołecznego Warszawy, Warszawa, s. 57-65.

Ma du row i c M. (2007), Miejska przestrzeń tożsamości Warszawy, Wydawnictwa Uniwersytetu Warszawskiego, Warszawa.

Ma jer A. (2010), Socjologia i przestrzeń miejska, Wydawnictwo Naukowe PWN, Warszawa.

P i o tro w s ki W. (1966), Społeczno-przestrzenna struktura m. Łodzi. Studium ekologiczne, Zakład Narodowy im. Ossolińskich, Wrocław-Warszawa-Kraków.

Pi otrowski W. (1994), Tożsamość miasta (na przykładzie Łodzi), [w:] Machaj I., Styk J. (red.), Stare i nowe struktury społeczne w Polsce. T. 1: Miasto, Wydawnictwo Uniwersytetu im. Marii Curie-Skłodowskiej, Lublin, s. 171-174.

P i ó r o Z. (1962), Ekologia społeczna w urbanistyce (na przykładzie badań lubelskich i toruńskich), Arkady, Warszawa.

P 1 u t a J. (2006a), Studium wrocławskiego autostereotypu, [w:] Ż u k P., P 1 u t a J. (red.), My Wrocławianie. Społeczna przestrzeń miasta, Wydawnictwo Dolnośląskie, Wrocław, s. 227-260.

Plu ta J. (2006b), Tożsamość i lokalność. Uwagi o zwiqzku wrocławian z przestrzeniq miasta, [w:] Ż u k P., Plu ta J. (red.), My Wroctawianie. Spoleczna przestrzeń miasta, Wydawnictwo Dolnośląskie, Wrocław, s. 59-74.

R y b i c k i P. (1972), Społeczeństwo miejskie, Państwowe Wydawnictwo Naukowe, Warszawa.

S i m me 1 G. (2008), Socjologia przestrzeni, [w:] te n ż e, Pisma socjologiczne, Oficyna Naukowa, Warszawa.

To p a lov Ch. (2002), Langage, société et divisions urbaines, [w:] To p a lo v Ch. (ed.), Les divisions de la ville, Éditions de la Maison des Sciences de l'Homme, Paris, s. 375-449.

Wa 11 i s A. (1990), Socjologia przestrzeni, Niezależna Oficyna Wydawnicza, Warszawa.

Zi ółk ow sk i J. (1960), Sosnowiec. Drogi i czynniki rozwoju miasta przemystowego, Wydawnictwo „Śląsk”, Katowice. 
Zi ółk o w s ki J. (1965), Urbanizacja, miasto, osiedle. Studia socjologiczne, Państwowe Wydawnictwo Naukowe, Warszawa.

Zn an i c ki F. (1931), Miasto w świadomości jego obywateli. Z badań Polskiego Instytutu Socjologicznego nad miastem Poznaniem, Wydawnictwo Polskiego Instytutu Socjologicznego, Poznań.

Zn a ni e c ki F. (1938), Socjologiczne podstawy ekologii ludzkiej, „Ruch Prawniczy, Ekonomiczny i Socjologiczny", z. 1, s. 89-119.

Znaniecki F., Ziółkowski J. (1984), Czym jest dla Ciebie miasto Poznań? Dwa konkursy: 1928/1964, Państwowe Wydawnictwo Naukowe, Warszawa-Poznań.

\title{
Stanisław Lisiecki, Jacek Kubera
}

\section{THE VALIDITY OF DISTRICTS OF CITY RESEARCH. SEARCHING FOR THE NEW-OLD IDENTITIES}

\begin{abstract}
In the article the district of a city is treated as a social space, which operates today within a big city, and which was once beyond its certain extent as a separate and autonomous being: as a village, a suburban area, a separate estate or a small town situated near a bigger city. With reference to the genesis of cities, the text describes the selected elements of urban districts' identity. Afterwards, with reference to selected urban sociology schools, different ways of understanding and describing the district are presented. Among the many possible perspectives, Authors consider particularly useful the one which may be called the identity approach. The tradition of conducting research in this trend was started in Poznan by Florian Znaniecki, and their characteristic is to draw attention to the autostereotype of residents living in a given place and study of this autostereotype in the context of other identities (eg. national, class, religious). Using the example of Poznan districts such as Śródka, Jeżyce, Św. Marcin or Wilda, the text speaks of the phenomena that form the modern identity of city's districts.
\end{abstract}

Key words: city, district, district's identity, identification with a district, Poznan. 